of Christ, but see worth in His teachings; $(c)$ those parents who do not themselves believe, but nevertheless wish their children to hear the Christian case and to decide for or against it later on; $(d)$ those who are opposed to changes of any kind.

Your proposal for "neutral" ethical instruction in schools provokes the question "Where do we go for sourcematerial ?" To highly controversial figures like Comfort, Crick, Arnold Lunn or the Bishop of Woolwich? To the writings of professional philosophers? I agree with you that the Old Testament is now not very useful as sourcematerial for ethics, its main claims to attention being cultural and historical. But why throw away the New Testament as a source? The principles laid down by Christ remain relevant-a fact of immense significance. It is quite possible to deny his divinity and yct to recognize that he was a man of immenso genius who changed the world for ever.

As we all know, it is going to be difficult enough for children to make decisions on ethical matters as it is. Let us try to help, not to hinder. Parents who do not bclieve might have real difficulty in giving such instruction at home, as you suggest they should.

$$
\begin{aligned}
& \text { Yours sincerely, } \\
& \text { H. N. V. TEMPERLEY }
\end{aligned}
$$

Department of Applied Mathematics,

University College of Swansea,

Singleton Park, Swansea.

\section{New Constitution for British Physicists}

SIR,--While I do not wish to endorse all that Professor Blackman said in his letter of January 4 (Nature, 221, 105; 1969), I think it is true that had members of the Physical Society realized, at the time of amalgamation with the Institute of Physics, that within a few years their identity would have disappeared altogether, that what was proposed was really a take-over, the offer would have been rejected or at least bitterly opposed.

Some of us have, in fact, taken a long time to realize just what was happening: a sad commentary, in many cases, on the pressure of papers on our desks.

I do think, however, that the council of the IPPS would do well, if it wishes to retain its reputation for scientific integrity, to take heed of tho advice given in your article (Nature, 220,$952 ; 1968$ ) and to allow more time for discussion within the joint organization. A year would not be too long.

\section{Yours sincerely,}

Kathleen Lonspate:

125A Dorset Road,

Bexhill-on-Sea,

Sussex.

\section{Probability and Prejudice}

SIR,--In the course of a book review (Nature, 221, 291 ; 1969) Professor M. S. Bartlett discusses the problem of three prisoners, two of whom are to be excecuted. His comments merit further discussion. He first remarks that if, as has been reported, the problem nearly wrecked a conference on theorotical biology and yet yields at once to Bayes's theorem, it does not say much for the conference participants. This seems a little hard on the theoretical biologists who will typically have learnt their probability from a member of the frequentist school who, if he mentioned Bayes's theorem at all, will have played it down as of minor interest. The fault surely lies with the statistician, not the biologist.

The second point is moro material. Bartlett draws the conclusion that subjective prior probabilities are indefinite.
The basis for this assertion seems to be that the prisoner, Matthew, is entitled to feel happier if $P$ (the probability of the jailer naming Mark if both Mark and Luke are to be executed) equals $3 r$. If $r>1 / 3$, the Bayesian analysis shows that this is impossible so that Matthew is inconsistent. If $r=1 / 3$, this requires $P=1$. Taking $r=1 / 3$ as a reasonable value, this shows that Matthew's clation is only justifiable (to him !) if ho believes that when there is a choice, the jailer will always name Mark. So I would say to Matthew, "If you feel elated it is equivalent to your assuming this preference on the jailer's part". Matthew would typically reply that he has no roason for thinking the jailer has such a preference: therefore, $\mathrm{I}$ say, he has no reason for feeling happier. The subjective probabilities must cohere and their value lies in doing just this-in the example in establishing coherence between Matthew's happiness and his opinion of the jailer. This seems to me to lead to a definite conclusion of some value, contrary to what has been said.

Yours sincerely,

Department of Statistics, D. V. LINDLEY

University College London,

Gower Street,

London WCl.

\section{International Meetings}

September 9-12, Conformational Analysis, Brussels (R. C. Smekens, Executive Sccretary, $49 \mathrm{Sq}$ Marie-Louise, Brussels 4, Belgium).

September 9-15, Foundry Congress, Belgrade (Professor M. B. Pajevic, Sevez Drustava Livaca SFRJ, Karnegijeva 4, Belgrade, Yugoslavia).

Septernber 14-19, International Society of Rehabilitation of the Disabled congress, Dublin (Joseph N. Malone, National Organization for Rehabilitation, 25 Clyde Road, Dublin 4, Ireland).

September 15-16, Bridge and Structural Engineering Symposium on Safety, London (A. R. Collins, Civil Engineering Research Association, Old Queen Street House, 6 Storey's Gate, London SWI).

September 15-17, Trunk Telecommunications by Guided Waves, London (Conference Department, The Institution of Electrical Engineers, Savoy Place, London WC2).

September 15-17, Programming Languages for Numerically Controlled Machine Tools, Rome (Dr E. L. Harder, c/o Westinghouse Electric Corporation, 1204 Milton Avenue, Pittsburgh, Pennsylvania 15218, USA, and Professor A. Caracciolo di Forina, Centro Studi Calcolatrici Elettroniche, University of Pisa, Pisa, Italy). September 15-17, Aerospace and Electronic Systems, Washington DC (Institution of Electrical and Electronics Engineers, Box A, Lenox Hill Station, New York NY 10021, USA).

September 15-17, Congress of World Veterinary Poultry Association, Belgrade (Professor L. Kozic, c/o Institute of Preventive Veterinary Medicine, Belgrade J. A., 8, Yugoslavia).

September 15-19, Tropical and Sub-tropical Fruits, London ('The Scientific Secretariat, Tropical Products Institute, 56-62 Gray's Inn Road, London WC1).

September 15-19, Electronics for Civil Aviation, London (Electronic Engineering Association, Berkeley Square House, Berkeley Square, London W1).

Septembor 15-20, Chemical Engineering, Chemical Equipment and Automation Congress, Marianske (III Chisa 1969, Czechoslovak Scientific and Technical Society, POB 857, Prague 1, Czechoslovakia). 
September 15-21, Funicular Transportation, Lucerne (Gilberto Greco, Chief of the Secretariat, International Organization for Transportation by Rope, 4 Via S. Martino Derra Battaglia, Rome, Italy).

September 15-21, Anaesthesia, Varna (Dr E. Stojanov, Bul. Batr. Evtimii 59, Sofia, Bulgaria).

September 16-19, International Federation of Surgical Golleges, Buenos Aires (R. S. Johnson-Gilbert, e/o Royal College of Surgeons, Lincoln's Inn Fields, London WC2).

September 17-20, Congress of Neurological Surgeons Meeting, Boston (Dr John M. Thompson, 1955 Blossom Way South, St Petersburg, Florida 33712, USA).

September 17-22, Land Subsidence, Tokyo (Arnold I. Johnson, c/o Water Resources Division, US Geological Survey, Federal Center, Denver, Colorado 80255, USA). September 17-24, Gyclotron Conference, Oxford and Harwell (Dr F. J. Stubbs, Chemistry Division, AERE, Harwell, Didcot, Berks, UK)

September 20-25, International Society of Surgery Congress, Buenos Aires (Professor E. Etala, c/o Societe Int. de Chirurgie, 43 Rue des Champs-Elysees, Brussels 5, Belgium).

September 20-27, Cardiovascular Society Congress, Buenos Aires (Dr Alan D. Callow, 171 Harrison Avenue, Boston, Massachusetts 02111, USA).

September 21-25, Plant Protection Research, Paris (Secretary-General, Societe Francaise de Phytiatrie et de Phytopharmacie, 57 Boul. Lannes, Paris 16, France).

September 21-25, Master Brewers Association of America Meeting, Toronto (Allan E. Beach, Executive Secretary, 154 E. Erie Street, Room 300, Chicago, Illinois 60611, USA).

September 21.-26, Papermaking Systems and their Gontrol, London (Technical Section, British Paper and Board Makers' Association, Plough Place, Fetter Lane, London EC4).

September 21-27, Neurological Surgery, New York (World Federation of Neurological Societies, c/o Johns Hopkins Hospital, 601 W Broadway, Baltimore, Maryland 21205, USA).

September 21-27, Mediterranean Phytopathological Union Congress, Avignon and Antibes (Dr J. Ponchet, Secretary-General, BP 79, 06-Antibes, France).

\section{Sabbatical Itinerants}

In the hope of providing some practical assistance in the good cause of mobility between laboratories, Nature is proposing to advertise the needs for housing of families about to take up periods of sabbatical leave. To begin with, no charge will be made for advertisements like this. It is hoped that a period of experiment will show what form these advertisements could most usefully take and whether they are effective.

Wanted : Three months from March 1, 1969; flat near to Imperial College, South Kensington, for visiting American professor and wife. Please contact Dr G. Borley, Department of Geology, Imperial College, London SW7.

Vacant : 4-roomed ground-floor flat in north-west London to let, suitable for a family with several children, newly decorated, fully furnished, garden, car space. 21 gns per week. Please write to B. Michelson, 43 Mapesbury Road, London NW2.

\section{BRITISH DIARY}

\section{Monday, February 10}

Instimution of Electricat Enarneers (at Savoy Place, London, WC2), t 2 p.m. and 5.30 p.m.- Meeting on "Noise in Rotating Electrical Sh, Papers by Mr A. J. Eillison, Mr C. J. Moore, Mr R. J. Davies and Mr D. D. Stephen.

institution of MEchantcat ENGINEeRs, NUClear ENergy Grodp at 1 Birdcage Walk, London, SW1), at 6 p.m.-Discussion meeting on "Oncethrough versus Circulating Boilers in Nuclear Power Plants".

\section{Tuesday, February 11}

ZOOLOGICAL SOCIETY OF LONDON (at the Zoological Gardens, Regent's Park, London, NW1), at 5 p.m.-Mr M. J. Holden: "The Distribution of some Species of Fish in Lake Albert, East Africa"; Professor K. Simkiss: "Where do the Bones of Embryos Come From ?"; "Zoologists at Work" (film).

UNIVERSITY OF LONDON (at Westminster Medical School, Horseferry Road, London, SW1), at 5.15 p.m.-Dr P. W. M. Copeman: "Drug Rashes".

INSTITUTION OF ELECTRICAL ENGINEERS, JOINT IEE/IERE MEDICAL AND Brological ELECTRONICS Grotp (at St Bartholomew's Hospital Medical School, London, EC1), at 5.30 p.m.--Professor D. R. Wilkie: "Muscle".

INSTITUTION OF ELEOTRIOAL ENGINEERS (joint meeting with the Automatic Control Group of the I.Mech.E., at Savoy Place, London, WC2), at 5.30 p.m.Mr B. May: " $p$ H Control of Effluent Disposal".

INSTITUTION OF THE RUBBER INDUSTRY (at the Eccleston Hotel, Eccleston Square, London, SW1), at 5.30 p.m.- "Mould Design" (speaker to be arranged); Mr H. Hurst: "Latex-siliconate Compositions for Damp Proofing"'.

UNIVERSITY OF LONDON (at the Institute of Child Health, Guilford Street, London, WC1), at 5.30 p.m.-Dr C. O. Carter: "The Genetics of some Common Malformations" (tenth of sixteen lectures on "The Scientific Basis of Medicine" organized by the British Postgraduate Medical Federation).

institution of Mechanione EngineERs, Automobile Division (at 1 Birdcage Walk, London, SW1), at 6 p.m.--Meeting on "Plastics in the ndustry".

INSTITUTION OF THE RUBBER INDUSTRY, WEST OF ENGLAND SECTION lat the George Hotel, Trowbridge), at 8 p.m.-Mr. P. Hill: "The Choice of Antioxidants for Synthetic Rubber Compounding"'.

Wednesday, February 12

UNIVERSITY of LoNDON (at the Royal Postgraduate Medical School, Du Cane Road, London, W12), at 2 p.m.-Dr P. Hamilton : "Epidemiology of Anaemia in the Tropics".

INSTITUTE OF NAVIGATiON (at the Royal Institution of Naval Architects, 10 Upper Belgrave Street, London, SW1), at 5 p.m.-Symposium on "Inertial Navigation",

UnIVERSITY OF LONDON (in the Physiology Lecture Theatre, University College London, Gower Street, London, WC1), at 5 p.m.-Professor C. de Duve (Louvain): "Lysosomes" (further lecture on February 13).

INSTITUTE OF FUEL (at the Duke of York's HQ, Sloane Square, London, SW3), at 5.30 p.m.-Mr M. G. Lacey: "Water Treatment-Current Practice and Future Developments".

Institution of EleCtrical ENGINeErs (at Savoy Place, London, WC2), at 5.30 p.m.-Dr G. G. Macfarlane: "Electronics Research and the Ministry of Technology"

Institution of Elemorrioal Enarneers (at Savoy Place, London, WC2), at 5.30 p.m.-Dr W. T. Norris: "The Use of Super-conducting Materials in Magnets"

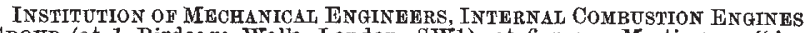
GRouP (at 1 Birdcage Walk, London, SW1), at 6 p.m.-Meeting on "An Experimental and Analytical Investigation of the Gas Exchange Process in a

SOCIETY OF ENVIRONMENTAL TNGINEERS (in the Mechanical Engineering Department, Imperial College, London, SW7), at 6 p.m.--Dr A. F. C. (1) "Air Conditioning for the Humironment".

SOcIety of Chemtcal Industry, OILS and Fats Group (at 14 Belgrave Square, London, SW1), at 6.15 p.m.-Dr R. Dils: "Biosynthesis and GLC of Triglycerides".

BrtTish SocikTY FOR THE History of Pharmacy (at the Pharmaceutical Society of Great Britain, 17 Bloomsbury Square, London, WC1), at 7 p.m.Miss A. J. O'Hara-May: "Foods as Materia Medica".

Wednesday, February 12-Thursday, February 13

IRON AND STEEL INSTITUTE (at the Royal Garden Hotel, London, W8)Meeting on "Mathematical Models in Metallurgical Process Control".

\section{Thursday, February 13}

Instirute OF Physics aNd the Phystcal Society, Vacutm Group (at

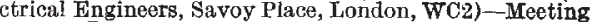
on "The Preparation of Thin Films by the Method of Sputtering".

CheMical Sooretr (in the Chemistry Lecture Theatre, Imperial College, London, SW7), at 2 p.m.--Symposium on "Structural Chemistry of Plant roducts".

RoYaL SOCIE TY (at 6 Carlton House Terrace, London, SW1), at 4.30 p.m.Mr L. A. B. Pilk ington: "The Float Glass Process" (Review Lecture).

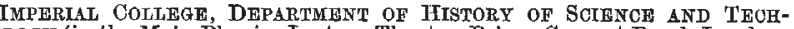
NoLOGY (in the Main Physics Lecture Theatre, Prince Consort Road, London, SW7), at 5 p.m.-Professor Everett Mendelsohn (Harvard University) "Helmholtz and the Problem of Reductionism".

UNIVERSITY OF LONDON (at the Institute of Child Health, Guilford Street, London, WC1), at 5.30 p.m.- Dr R. T. C. Pratt: "“The Implications for
Neurology of Recent Advances in Medical Genetics" (eleventh of sixteen lectures on "The Scientific Basis of Medicine" organized by the British Postgraduate Medical Federation). 